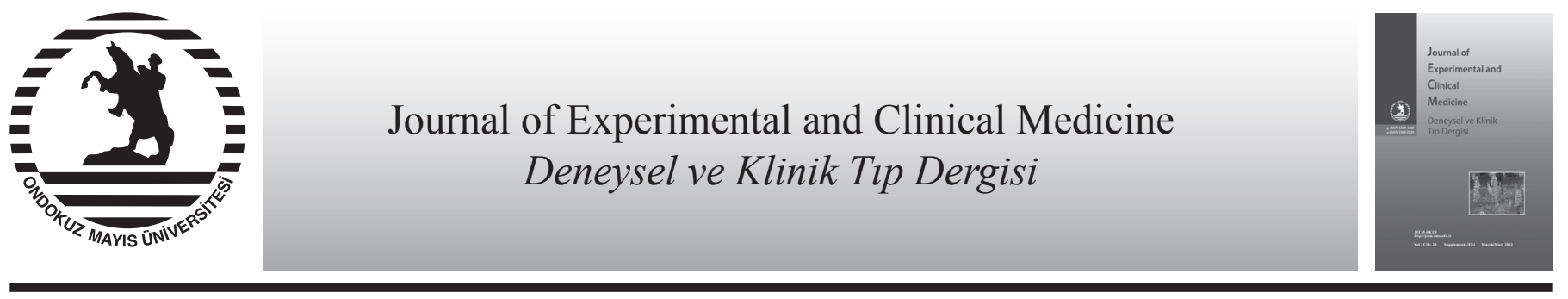

Derleme / Review

doi: $10.5835 /$ jecm.omu.29.s1.005

\title{
Diyabet ve egzersiz
}

\section{Diabetes and exercise}

\section{Çiğdem Tura Bahadır, Hulusi Atmaca*}

Ondokuz Mayıs Üniversitesi, Tıp Fakültesi, Endokrinoloji ve Metabolizma Hastalıkları Bilim Dalı, Samsun, Türkiye

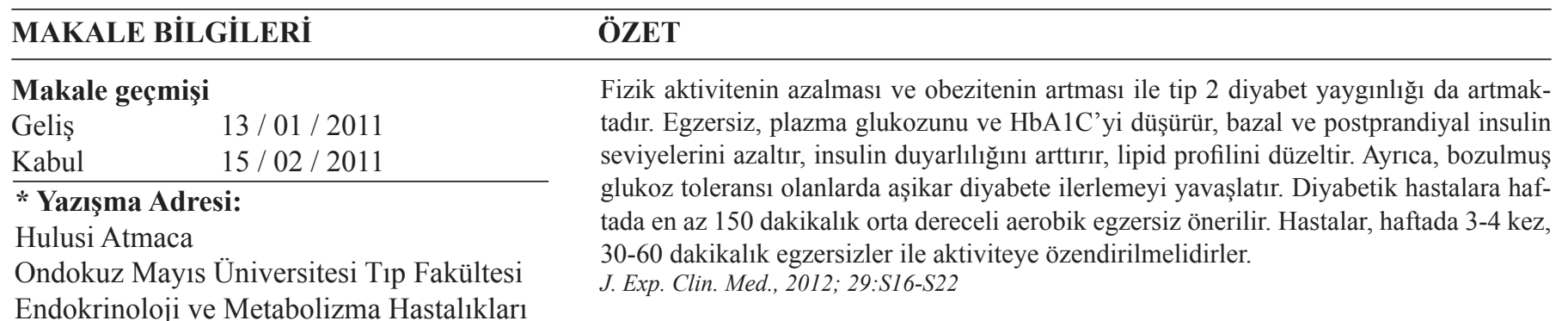

Bilim Dal1, 55139, Atakum/Samsun

e-posta:hatmaca@yahoo.com.

\section{Anahtar Kelimeler: \\ Egzersiz \\ Diabetes mellitus \\ Bozulmuş glukoz toleransı \\ İnsulin duyarlılığg \\ Kardiyovasküler risk \\ Gebelik}

\author{
Keywords: \\ Exercise \\ Diabetes mellitus \\ Impaired glucose tolerance \\ Insulin sensitivity \\ Cardiovascular risk \\ Pregnancy
}

\begin{abstract}
The incidence of type 2 diabetes mellitus increases with the decrease in physical activity and increase in obesity. Exercise decreases plasma glucose, $\mathrm{HbA1C}$, basal and postprandial insulin levels; increases insulin sensitivity and improves lipid profile. It also slows down progress into type 2 diabetes mellitus those with impaired glucose tolerance. At least 150 minutes of moderate aerobic exercise per week is recommended to diabetic patients. Patients should be encouraged for activity for 30-60 minutes of exercises 3-4 times a week.

J. Exp. Clin. Med., 2012; 29:S16-S22
\end{abstract}

(C) 2012 OMU

\section{Egzersizin yararları}

Fizik aktivitenin azalması ve obezitenin artması ile tip 2 diyabet yaygınlığı da artmaktadır (Zinman ve ark., 2004). Egzersiz plazma glukozunu ve HbA1C'yi düşürür, bazal ve postprandiyal insulin seviyelerini azaltır, insulin duyarlılığını arttırır, lipid profilini düzeltir. Kas GLUT-4 seviyesini arttırır, kardiyovasküler zindelik sağlar, öfori verir. Bozulmuş glukoz toleransı olanlarda aşikar diyabete ilerlemeyi yavaşlatır (Konca ve Ayvaz, 2011). En az 8 hafta egzersiz yapılması sonucu vücut kitle indeksinde (VKİ) önemli değişiklik olmasa da, HbA1C düzeyinde ortalama \%0,66 düşüklük saptanmiştır (Peyrot ve ark., 2005).

Diyabetik hastalara haftada en az 150 dakikalık orta dereceli aerobik egzersiz önerilir (en yüksek kalp hızının \%5070'i kadar. En yüksek kalp hızı=220-yaş olarak hesaplanır). Komplikasyonu olmayan tip 2 diyabetli hastalara ise daha dirençli egzersiz programları önerilmelidir (American Diabetes Association, 2011). Ağırlık ile yapılan yüksek dirençli egzer- sizler genç hastalarda uygulanmalı, yaşlı hastalarda ve uzun süreli diyabeti olanlarda ise önerilmemelidir. Hafif ağırlık ve sık tekrar ile yapılan ılımlı egzersizler ile üst gövde kesiminin güçlendirilmesi hemen hemen tüm hastalarda önerilmelidir (Zinman ve ark, 2004).

Egzersiz programına başlamadan önce hastalar bazı açılardan değerlendirilmelidirler. Hastaların glisemik kontrol düzeyi ve HbA1C değeri değerlendirilmeli, kardiyovasküler sistem muayenesi yapılmalıdır (Konca ve Ayvaz, 2011).

\section{Egzersiz fizyolojisi}

Glukozun \%50'si beyin, \%15-20'si iskelet kasları, geri kalanı böbrek, iç organlar, eritrositler ve diğer dokular tarafindan tutulur (Steppel ve Horton, 2008).

Açlıkta, erken zamanda karaciğer tarafindan glukoz üretimi asıl olarak glikojenoliz ile oluşur, glikoneogenez katkısı \%25 civarındadır. Hatta açlığın erken zamanında, tip 1 diyabetli hastalarda egzersizin yapılmadığı sirada glukoz üre- 
timinin \%45'ten fazlası glikoneogenezden oluşur (Steppel ve Horton, 2008).

Egzersiz sırasında, anaerobik metabolizma aerobik metabolizmaya dönüşür, kas hücrelerine oksijen ve glukoz girişi artar. Glukoz konsantrasyonu, karaciğerde glukoz üretimi, dolaşıma verilmesi ve kaslar tarafından da alınması, kullanılması ile sabit tutulur. Egzersiz sırasında glukoz tutulumunun moleküler mekanizmaları insulinden bağımsızdır. Bu nedenle serum insulin düzeyindeki azalma kasların dolaşımdan glukoz almalarını etkilemez (Steppel ve Horton, 2008).

Uzamış ve zorlu egzersiz sırasında glukoz seviyesinin düzenlenmesinde glukagon önemlidir. Glukoneogenezi artt1rır. Glukagonun oynadığı rol antrenmanlı sporculardan ziyade egzersiz yapmayanda daha fazladır. Kortizol ve büyüme hormonu da insulin etkilerini bloke eder (Steppel ve Horton, 2008).

Egzersiz sonrası insulin etkisindeki iyileşme kas glikojen depolanması için gereklidir. İnsulin etkisinin düzelmesindeki birincil sorumlu GLUT-4'teki değişimlerdir. GLUT-4, insulin veya insulin dışı (kontraktilite, hipoksi gibi) uyarılarla hücre membranına hareket eden hücre içi bir proteindir. Glukozun düşük konsantrasyondan hücre içine difüzyonuna imkan sağlar. Egzersiz, plazma membranında GLUT-4 miktarını arttırmanın yanısıra, taşıyıcıların intrensek aktivitesini de arttırmaktadır (Douen ve ark., 1990). Egzersiz sırasında kaslar 2-3 $\mathrm{mg} / \mathrm{kg} / \mathrm{dk}$ glukoz tüketirler (George ve ark., 2005). Egzersiz ile glukoz kontrolündeki iyileşmenin muhtemel mekanizmaları Tablo 1'de gösterilmiştir (Ivy ve ark., 1999; Wojtaszewski ve ark., 2002).

Egzersiz süresi içinde bir hafta gibi kısa bir sürede insulin etkisindeki ve glukoz toleransindaki düzelme, kilo vermeden bağımsız olarak meydana gelebilmektedir. Bazı araştırmalar, ardışık 7 gün boyunca $50 \mathrm{dk}$ üzerinde, maksimum kalp hızı rezervi (MHRR) \%70-75 olacak şekilde yapılan egzersiz sonrası, obez ve bozulmuş glukoz toleransı olan populasyonda \%35 oranında insulin sensitivitesinde artma ve glukoz toleransında iyileşme saptamışlardır (Rogers ve ark., 1988; Brown ve ark., 1997).

Egzersiz başlangıcındaki insulin etkisindeki iyileşme, kilo vermeden bağımsız, egzersiz sonucu bir adaptasyon mekanizması ile olmaktadır. Uzun süreli iyileşmede hem adaptasyonların hem de kilo vermenin her ikisinin de etkili olduğu düşünülmektedir (David ve ark., 2001).

Bir çok faktör yakıt kullanımını değiştirebilir: Fiziksel antrenman, yoğun egzersiz, egzersizin süresi ve egzersizden önce alınan diyet. Antrenmanlı bireylerde yakıt olarak glukozdan ziyade serbest yağ asitleri kullanılmaktadır. Bu dayanma gücünün artmasında önemli bir rol oynar. Çünkü antrenmanlı bireylerde kas glikojen depoları antrenmansız bireylerde olduğu kadar hızlıca boşalmaz.

Egzersiz yoğunluğu maksimum aerobik kapasite yüzdesi $\left(\mathrm{VO}_{2} \mathrm{max}\right)$ olarak tanımlanır. Egzersiz yoğunluğu arttıkça, glukozun egzersiz kaslarında yakıt olarak kullanımı artar, lipoliz azalır, aminoasit aynı kalır. $\mathrm{VO}_{2} \max \% 75$ 'den fazla ise karbonhidratlar kaslar tarafindan kullanılan ana yakıt olur ve glikojenoliz artar (Steppel ve Horton, 2008). $\mathrm{VO}_{2} \max$ $\% 75$ 'ten fazla olan yoğun egzersizler sonucu insulin etkisinde bozulmalar olabilmektedir (David ve ark., 2001).

İnsan vücudu normal şartlarda aerobik metabolizma ürünleri olan serbest oksijen radikalleri üretir. Hücre memranındaki lipid peroksidasyonu, hücre membranında yapısal değişikliklere neden olur ve bu hücre fonksiyonunu inhibe eder. Yoğun egzersiz boyunca yüksek miktarda, oksidatif doku hasarına sebep olabilen, serbest oksijen radikalleri üretilir. Hem kontrregüler hormonlar hem de serbest radikaller geçici glukoz intoleransına neden olabilmektedir (David ve ark., 2001). Bayır aşağı koşmak (Sherman ve ark., 1992) dirençli egzersiz (King ve ark., 1993) sonucu, kas hasar belirteci olan kreatinin kinazda belirgin artı̧̧ ve egzersizden hemen sonra insulin sensitivitesinde artmaya neden olur. (Schell ve ark., 1999).

Tek sefer dirençli egzersiz sonrası glukoz yüklemesine olan insulin cevabının, tek sefer koşu bandındaki koşu sonrasına göre daha fazla olduğunu bulmuşlardır. Bu durum bize dirençli egzersizle meydana gelen hasar sonucu insulinin etkisinde azalma olduğunu göstermektedir (David ve ark., 2001).

Egzersiz süresi uzadıkça, glikojen depoları birkaç saat içinde tükenir ve lipoliz egzersiz yapan kas için ana yakıt kaynağı olur. Karaciğerde glikoneogenez ile glukoz üretimi olur (Steppel ve Horton, 2008). King ve arkadaşları (1995) 5 gün boyunca, günde $45 \mathrm{dk}, \mathrm{VO}_{2} \max \% 73$ olan egzersiz rejiminin hemen sonrasinda, oral glukoz tolerans testinde (OGTT) insulin ve glukoz cevabında belirgin bir artma saptamışlardır. Katekolamin gibi kontrregüler hormonların artışı sonucu insulin toleransında azalma olmaktadır. Plazma serbest yağ asitlerinin düzeyi OGTT boyunca ölçüldügünde egzersiz hemen sonrasında belirgin artış saptanır.

Egzersiz öncesi karbonhidrat bakımından zengin diyet alan bireylerde, karbonhidrattan kısıtlanmış diyetle beslenen bireylere göre genel olarak daha fazla dayanma gücü görülmüştür. Çünkü karbonhidrattan zengin diyetle glukoz oksidasyon hızı daha çok artar ve kas glikojen depoları artış gösterir (Steppel ve Horton, 2008).

\section{Egzersiz hazırlığı}

Diyabet eğitimi içinde hemşire, diyetisyen, mesleki terapist, eczac1, hekim, fizyoterapist, optometrist, ayak uzman1, sosyal yardım uzmanı, klinik psikolog, egzersiz fizyoloğu, sağlık eğitmeni yer almalıdır (Catherine ve ark., 2005).

Güvenli ve eğlenceli fiziksel aktivite programları hazırlamak önemlidir (Zinman ve ark., 2004). Uygun egzersiz programı kişinin hedeflerine (kilo verme, mevcut kiloyu koruma, glisemik kontrol, kuvveti artırma, tahammülü artırma gibi), egzersiz/fizik aktivite öyküsüne, diyabet öyküsüne (diyabet süresi, komplikasyon varlığı, tedavi, kan glukoz düzeyinin monitörizasyon sıklığı, hipoglisemi sıklığı-şiddeti ve egzersiz ile ilişkisine, HbA1C düzeyine, sağlı durumuna (nöropati varlığı, ayak deformiteleri, geçmiş veya yeni açık yaralar, retinopati, maküler ödem, glokom, nefropati, koroner arter hastalığı, konjestif kalp yetersizliği (KKY), periferik vasküler hastalık, serebrovasküler olay), ortopedik problemlerine, motivasyonuna ve psikolojik durumuna göre belirlenir (Catherine ve ark., 2005).

Tüm tip 2 diyabetiklerde ve 10 yıl üzeri tip 1 diyabetiklerde veya $>3-5$ y1 tip 1 diyabetiklerde egzersiz programı başlamadan önce göz muayenesi yapılmalıdır (Catherine ve ark., 2005). Ev işleri, boş zamanları değerlendirmek için yapılan aktiviteler de egzersiz değerlendirmesinde dikkate alınmalıdır (Catherine ve ark., 2005). Hipertansiyon ve ortostotik hipotansiyon, senkop, düşme öyküsü, egzersiz dispnesi, dislipidemi, aldığı tedavi ve yan etkileri değerlendirilmelidir. Kardiyak risk faktörleri saptanmalıdır. 


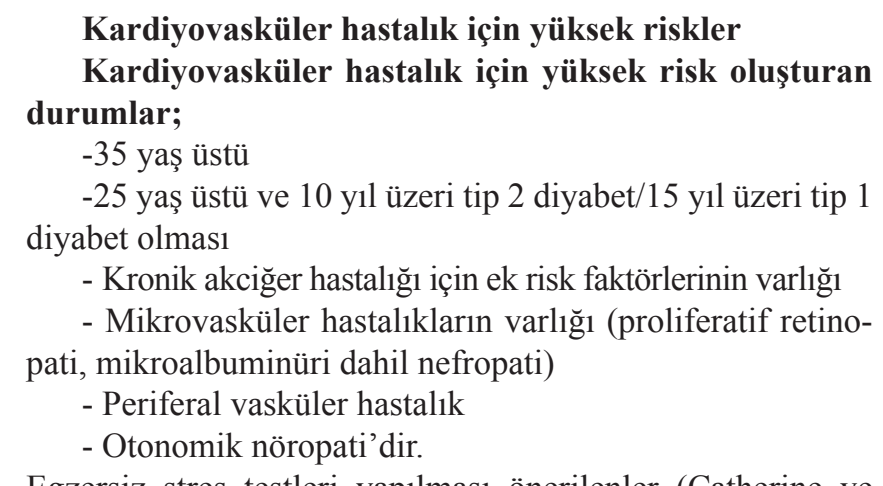

Egzersiz stres testleri yapılması önerilenler (Catherine ve ark., 2005);

- Diyabetten başka kardiyovasküler risk faktörü olsun veya olmasın 40 yaşın üzerindekiler

- 30 yaşın üzerinde ve

- 10 yıldan uzun süreli tip 1 veya tip 2 diyabet

- Hipertansiyon (HT)

- Dislipidemi

- Sigara

- Proliferatif ve preproliferatif retinopati

- Nefropati, mikroalbuminüri varsa

- Yaştan bağımsız olarak

- Bilinen veya şüphelenilen koroner arter hastalığı, serebrovasküler hastalık ve/veya periferal vasküler hastalık varsa

- Otonomik nöropati

- Böbrek yetmezliğine ilerlemiş nefropati varlığında

Eğer hasta kalp hızını en fazla \%60 artıracak şekilde, yürüme gibi hafif yoğunlukta egzersiz yapacak ise egzersiz stres testlerinin yapılıp yapılmayacağına, hasta kliniğine göre karar verilmelidir (Zinman ve ark., 2004).

Egzersiz, hastaların psikolojilerine iyi gelmektedir. Ancak egzersizin başlangıcında hastalar anksiyete, depresyon ve stres açısından değerlendirilmelidirler.

Bel ve boyun ağrısı, kalçada dejeneratif eklem hastalığı, plantar faciit, omuz ağrısı ve diz ağrısı gibi kimi ortopedik durumlar egzersiz ve aktiviteyi kisitlar (Catherine ve ark., 2005). Bazı hastaların bel ağrısı yürümekle artar ve oturmakla, binicilik, kondisyon bisikleti gibi arkaya yaslanmalı aktiviteler ile azalır. Kimi hastaların bel ağrısı ise yürümekle rahatlar.

70 kg ağırlığındaki bir kişinin $150 \mathrm{kcal}$ enerji harcaması için $40 \mathrm{dk}$ 'da toplam $5 \mathrm{~km}$ yürümesi, $30 \mathrm{dk}$ 'da toplam $8 \mathrm{~km}$ bisiklete binmesi, $30 \mathrm{dk}$ dans etmesi veya masa tenisi oynaması, $20 \mathrm{dk}$ yüzme veya basketbol oynaması, $15 \mathrm{dk}$ ip atlaması gerekmektedir.

\section{Kronik komplikasyonu olan diyabetlilerde egzersiz Retinopati}

Diyabete bağlı proliferatif retinopati ve ciddi nonproliferatif retinopatide zorlu aerobik ve dirençli egzersiz, vitreusta kanama ve retinal ayrılma riskinden dolayı kontrendike sayılmaktadır (Schriger ve ark., 1997).

\section{Periferal nöropati}

Derin tendon refleksleri, dokunma duyusu, vibrasyon ve pozisyon duyuları değerlendirilmelidir. On gramlık monofilaman ile dokunma duyusunun algılanamaması, koruyucu duyuların kaybının bir göstergesidir (Zinman ve ark., 2004). Ekstremitelerde ağrı hissinde azalma sonucu cilt hasarı ve enfeksiyon, charcot eklem riski artmaktadır. Ilımlı yoğunluktaki yürüyüşün, ayak ülserlerini ve tekrarlayan ülser oluşumuna genellikle sebep olmadığı görülmüştür (Aubert ve ark., 1998). Periferal nöropatisi olan hastalar ayaklarına uygun ayakkabı giymeli ve herhangi bir yara oluşumunun erken tespiti için ayaklarını günlük olarak kontrol etmelidirler. Ayaklarında açık yarası ve hasarı olanlarda yük bindirici olmayan egzersizlerin de kısıtlanması gerekmektedir. Periferal nöropati sonucu koruyucu duyu kaybına uğrayan diyabetik hastalar için egzersizler Tablo 3 'te gösterilmiştir (Zinman ve ark., 2004).

\section{Otonom nöropati}

Otonomik nöropati egzersize bağlı yaralanma, egzersize kardiyak yanıtsızlık, postural hipotansiyon, isı regulasyonunda bozulma, pupiller reaksiyonda bozulma nedeni ile karanlikta görmede bozulma, gastroparezi nedeni ile hipoglisemiye yatkınlık riskini artırır (Knight, 2005). Diyabetik otonomik nöropatili hastalarda fizik aktiviteye başlamadan önce kardiyak değerlendirme yapılmalıdır (ADA, 2011). İstirahat veya stres talyumlu miyokard sintigrafileri makrovasküler koroner arter hastalığın varlığını göstermek için uygun, noninvaziv testlerdir.

Otonomik nöropatili hastalarda özellikle fiziksel aktivite programı başladığında, zorlu fiziksel aktivite sonrası hipotansiyon ve hipertansiyon meydana gelebilmektedir. Isı regülasyonunda da bozukluk meydana gelmesinden dolayı sıcak veya soğuk mekanlarda fiziksel aktiviteden kaçınmaları ve hidrasyonlarına dikkat etmeleri öğütlenmelidir (Zinman ve ark., 2004).

\section{Albuminüri ve nefropati}

Aşikar nefropatisi olan hastalarda, sıklıkla fiziksel aktivitelerini kisitlayan egzersiz kapasitelerinde azalma meydana gelmektedir (Zinman ve ark., 2004). Fizik egzersiz akut safhada idrar ile protein atılımını arttırır. Ancak zorlu egzersizin, diyabete bağlı böbrek hastalığını ilerlettiğini gösteren bir kanıt yoktur. Egzersizin tüm komponentleri (sıklık, yoğunluk, süre, tip) hastanın klinik durumuna ve hedeflere göre değerlendirilmeli ve planlanmalıdır (David ve ark., 2001).

Genel olarak;

\section{Sıklık}

Egzersizin başlangıcında hastalar, her egzersiz arasında 24 saat dinlenme süresi olmak üzere, haftada 3-4 kez aktiviteye özendirilmelidirler (David ve ark., 2001).

\section{Yoğunluk}

Haftada en az 150 dak'lik orta dereceli aerobik egzersiz önerilir (en yüksek kalp hızının \%50-70'i kadar). En yüksek kalp hızı= 220-yaş olarak hesaplanır (Konca ve Ayvaz, 2011). Fiziksel aktivite yoğunluğunun sınıflandırılması Tablo 2'de gösterilmiştir (Zinman ve ark., 2004).

\section{Süre}

30-60 dk'lık egzersizler yapılmalıdır. Eğer hasta $30 \mathrm{dk}$ egzersiz yapamıyor ise daha kısa aralıklar ile başlamasına izin verilir (David ve ark, 2001).

\section{Egzersiz tipi}

Egzersiz, büyük kas gruplarını kapsamalıdır. Merdiven çıkma, yürüme, yavaş koşu, bisiklet sürme iyi birer seçim olacaktır. Koşu bandı hız kontrolü yapılabildiği için kullanışlı olabilmektedir. 


\section{Motivasyon ve pratik öneriler}

Parmaktan stik ile kan glukoz düzeyinin ölçümü hastalara pozitif feedback sağlayabilir. Hastalara egzersiz seçenekleri sunulabilir, böylece hastalar yaşam biçimlerine uygun egzersiz tipini seçebilirler.

Egzersiz için aerobik fiziksel aktiviteler önerilmektedir. Standart ısınma ve soğuma periyodları olmalıdır. Isınma kalbi, kasları, akciğerleri daha yoğun egzersizlere hazırlamak için yapılır. Isınma periyodunda $10-15$ dk'lık yürüme, bisiklete binme gibi hafif aerobik aktiviteler yapılmalıdır. Kısa 1sınma periyodu sonrası kaslar 5-10 dk nazikçe gerilmelidir. Özellikle aktivite sırasında kullanılacak kasların gerilmesiyle birlikte tüm kaslar 1sındırılmalıdır. Aktif egzersiz sonrası ise 1sınma hareketlerine benzer şekilde soğuma hareketleri yapılmalıdır. Soğuma hareketleri için 5-10 dk. yeterlidir, böylece kalp hızı egzersiz öncesi hıza düşürülür (Zinman ve ark., 2004).

Egzersiz için ayak bakımı önemlidir. Silika jeller, polyester veya pamuk-polyester çoraplar su toplamasına ve ayağın kuru tutulmasına karşı önemlidir. Uygun ayakkabı, özellikle periferik nöropatisi olan hastalarda önemlidir. Egzersiz öncesi ve sonrası herhangi bir yara veya su toplaması olup olmadığı kontrol edilmelidir (Zinman ve ark., 2004).

Hastanın, egzersiz yaparken diyabet hastası olduğunu belirten bir rozeti veya bileziği görünür şekilde takmaları, uygun hidrasyonun sağlanması (hem kan glukoz seviyesini hem de kardiyak fonksiyonları etkilediğinden dolayı) önemlidir. Egzersizden 2 saat öncesinde sıvı tüketimi önerilir (Zinman ve ark., 2004).

\section{Bozulmuş glukoz toleransı ve egzersiz}

Bozulmuş glukoz toleransı (BGT) olan hastalarda yaklaş1k 10 y1l içinde tip 2 diyabet gelişmektedir. Bu nedenle BGT olan hastalarda aralıklı 1lımlı fizik aktivite yarar sağlamaktadır. Ilımlı yoğunluk 3-6 metabolik eşdeğer (MEDS) veya 11$12 \mathrm{ml} / \mathrm{kg} / \mathrm{dk}$ oksijene tekabül etmektedir. Her ne kadar daha yüksek yoğunluktaki fizik egzersiz daha iyi glukoz homeostazisi sağlasa da mekanik ve oksidatif hasar sonucu insulin etkisini ve glukoz toleransını bozabilmektedir (David, 2001).

Düzenli dirençli egzersiz sonucu (10-15 dakikalık seanslar halinde, haftada 2-3 kez, 1lımlı yoğunluktaki egzersiz) BGT olan ve tip 2 diyabetik hastalarda HbA1c düzeyinde \% 0,4-0,5 azalma saptanmıştır (Castaneda, 2002; Boule, 2003; Snowling, 2006; Thomas, 2006; Nelson, 2007; Sigal, 2007). Daha yoğun egzersizler, egzersiz sonrası kalori harcamasını arttırır. Egzersizin kesilmesinin ardından artmış vücut metabolizması sonucunda enerji harcanması artar. Tekrarlayan egzersizler ile enerji tüketimi arttıkça da kilo verme gerçekleşir. $30 \mathrm{dk}$ 1lımlı egzersiz sonrası harcanan kalori yaklaşık 150-200 kcal/gün'dür. Hem akut hem de uzun süreli egzersiz uygulamalarında insulin etkisi üzerine temel belirleyici faktör egzersizin yoğunluğudur (David ve ark, 2001).

\section{Tip 1 diyabet ve egzersiz}

Tip 1 diyabeti olan bireylerde, diyabeti olmayan bireylerden farklı olarak, egzersiz yaparak artırılan pankreas adacıklarındaki düzenleyici olaylar insülin salınımını azaltmazlar. Çünkü insülin, enjeksiyon ile sağlanır ve insulin düzeyleri korunur, karaciğer üzerinde insulinin baskılayıcı etkisi devam eder, glikojenoliz ve glikoneogenezin normal upregülasyonu oluşmaz ve bu hipoglisemi ile sonuçlanır (Steppel ve Horton, 2008).
Hastalık süresi kısa süreli tip 1 diyabet hastalarında, uzun süreli tip 1 diyabetiklerdeki gibi komplikasyonlara yönelik geniş testler yapılmasına gerek yoktur. Egzersize bağlı hipoglisemi göz önünde bulundurulduğunda glisemik kontrol için tedavi düzenlenmesinde yeme planı, egzersiz, oral ajanlardan insulin tedavisine kadar her şey değerlendirilmelidir. Egzersiz sirasında, egzersiz öncesinde ve sonrasında kan glukoz konrolü yapılmalı, insulin ve ek karbonhidrat ihtiyacı belirlenmelidir. Genelde glukoz tabletler, glukoz jel, sporcu içecekleri ve şekerden bu ihtiyaç karşılanır. Özellikle tedavi değişimi ve egzersiz değişikliği yapıldığında dikkatli olunmalıdır. Hastaya hipoglisemi özellikle sorulmalıdır. Çünkü hastalar unutabilir, hipoglisemiyi kendileri düzeltebilir ve kilo alabilirler (Catherine ve ark., 2005).

İyi glisemik kontrolü olan ve komplikasyonu olmayan Tip 1 diyabetli hastalarda, ister boş zamanları doldurucu tarzda, ister yarışmalı profesyonel performans gerektiren fizik aktiviteler olsun, hepsi de yapılabilmektedir. Önemli olan hastaların fizik aktiviteye verilen glukoz cevabının monitorizasyonunun düzgün yapılmasıdır (Zinman ve ark., 2004). Farklı egzersiz tipleri kan glukoz seviyelerinde farklı etkiler yaratır. Örneğin; kısmen korunan aktivite plazma glukoz konsantrasyonunu düşürebilir ve hipoglisemi olur, yüksek yoğunluktaki eforun ani patlamaları glukoz seviyelerini arttırabilir ve hiperglisemi olur. Yoğun egzersiz ile kan glukozundaki artış tip 1 diyabetli bireylerde diyabeti olmayanlara göre daha uzun devam edebilir. $\% 80 \mathrm{VO}_{2}$ max'da egzersiz yapan tip 1 diyabetli hastalarda egzersiz sonrası hipergliseminin daha yüksek seviyelere ulaştığı ve tam 2 saat içinde sonlandığı bulunmuştur (Mitchell ve ark., 1988). İnsulin düzeyi egzersiz öncesi ve sonrası da düşürülebilir. Bu miktar egzersiz şiddetine, süresine ve hastanın geçmiş egzersiz tecrübesine göre değişebilmektedir (Catherine ve ark., 2005). Bu çoğu kez egzersiz öncesinde insulin dozunu \%25'ten \%50'ye kadar azaltmakla ve insülin aldıktan sonra en az bir saat içinde egzersizden kaçınmakla mümkündür. İnsulin pompası kullananlarda bazal hız düşürülmeli, yemek öncesi doz azaltılmalıdır. Genel kural, kısa etkili insulinlerin dozunun yemeklerden önce $\% 50$ azaltılması, uzun etkili insülinlerin dozunun \%30-35 azaltılmasidır (Steppel ve Horton, 2008).

Fizik aktiviteye glukoz cevabını düzenlemek için (Zinman ve ark., 2004);

1. Fizik aktviteden önce metabolik kontrol sağlanmalıdır.

- Eğer kan glukoz düzeyi $>250 \mathrm{mg} / \mathrm{dL}$ ve ketozis var ise aktiviteden kaçınılmalıdır, eğer kan glukoz >300 mg/dL ancak ketozis yok ise ihtiyatlı olunmalıdır.

- Kan glukoz $<100 \mathrm{mg} / \mathrm{dL}$ ise ek karbonhidrat alınmalıdır.

2. Fizik aktivite öncesi ve sonrasında kan glukoz düzeyi kontrol edilmelidir.

- İnsulin değişiminin veya gıda alımının gerektiği zamanlar bilinmelidir.

- Farklı fizik aktiviteye verilen glukoz cevapları öğrenilmelidir.

3. Yiyecek alımı

- Hipoglisemiden kaçınmak için ek karbonhidrat tüketilmelidir.

- Fizik aktivite boyunca ve sonrasında karbonhidrat bazlı yiyeceklere kolayca ulaşılabilmelidir.

Tip 2 diyabet ve egzersiz

Tip 2 diyabet hastalarında egzersiz ile alfa hücreleri etki- 
lenmezken, beta hücre fonksiyonlarında artış görülmektedir. Tip 2 diyabet hastalarında beta hücre adaptasyonu mevcut sekretuar kapasiteye bağlıdır ve HbA1C düzeyi ile insulin sensitivitesinde değişiklik olmasa da görülebilir (Dela ve ark., 2004). Bazı tip 2 diyabet hastalarındaki komorbid durumlar ve hareket kabiliyetindeki azalma hastaların egzersiz kapasitelerini azaltmaktadır (Pariser ve ark., 2010).

Glisemik kontrol: Yoğunluğu $\mathrm{VO}_{2} \max \% 50-80$ olan ve haftada 3-4 kez, 30-60 dk yapilan fizik aktivitelerin uygulandığı çalışmalarda, özellikle hafif diyabeti ve belirgin insulin direnci olan diyabetik hastalarda HbA1C'deki iyileşme \%1020 görülmüştür.

Düzenli kardiyovasküler egzersiz programı (30-60 dk, haftada 3-4 kez, maksimal kalp hiz rezervinin \%60-75'i olacak şekilde 1 lımlı yoğunlukta, 12 hafta ve üstü yapılan egzersiz) glukoz düzeylerini iyileştirir ve tip 2 diyabete gidişe karşı hastayı korur (Tuomilehto ve ark., 2001; Sigal ve ark., 2007). Metaanalizler ılımlı kardiyovasküler egzersiz programının tip 2 diyabetli hastalarda $\mathrm{HbA1C}$ düzeyinde \%0,6-0,7'lik azalma, insulin sensitivitesinde $\% 28$ artış ve açlık insulin düzeyinde \%20'lik azalma sağladığı gösterilmiştir (Boule ve ark., 2003; Thomas ve ark., 2006). Düzenli dirençli egzersiz sonucu (10-15 dakikalık seanslar halinde, haftada 2-3 kez, 1lımlı yoğunluktaki egzersiz) BGT olan ve tip 2 diyabetik hastalarda HbA1C düzeyinde \%0,4-0,5 azalma saptanmıştır (Thomas ve ark., 2006; Boule ve ark., 2003; Snowling ve Hopkins, 2006; Sigal ve ark., 2007; Nelson ve ark., 2007; Castaneda ve ark., 2002).

Tip 2 diyetiklerde kardiyovasküler ve dirençli egzersiz programının beraber uygulanması sonucunda HbA1C'de $\% 0,8$ düşüş, insulin sensitivitesinde $\% 106$ artış ve açlık insulin değerinde \%7 azalma görülmüştür (Thomas ve ark., 2006; Snowling ve Hopkins 2006).

Rezistan egzersize cevap olarak kas kitlesinde artma, glikojen depolanmasında artma, insulin bağımsız glukoz taşıyıcılarında artma ile glukoz kontrolünde iyileşme sağlanır (Cuff ve ark., 2003; Snowling ve Hopkins, 2006; Thomas ve ark., 2006; Gulve, 2008).

\section{a) Kardiyovasküler koruma}

Fizik aktivitenin kardiyovasüler risk üzerine yararlı etkisi, insulin sensitivitesini arttırmasından ileri gelmektedir.

\section{b) Hiperlipidemi}

Düzenli fizik aktivite trigliserid zengin VLDL düzeyini azaltır. LDL için böyle bir durum henüz dökümente edilmemiştir. Egzersiz tip 2 diyabetiklerde de HDL düzeyini artırmaktadır.

\section{c) Hipertansiyon}

İnsulin rezistansı ve HT birbiriyle bağlantılıdır. Hiperinsulinemik hastalarda fizik aktivite ile kan basıncının azaldığı gösterilmiştir.

\section{d) Fibrinolizis}

Pek çok tip 2 diyabetli hastada plazminojen aktivitör inhibitörü-1'in (PAI-1) artmasıyla fibrinolitik aktvitede bozulma olur. Özellikle doku plazminojen aktivitörü (t-PA) inhibitöründe bu olmaktadır. Çalışmalar aerobik kabiliyet ile fibrinolizin ilişkili olabileceğini göstermiştir. Ancak fizik aktiviteninin fibrinolizi iyileştirdiğine dair fikir birliği yoktur (Zinman ve ark., 2004).

\section{e) Obezite}

Fizik aktivite kilo kaybını sağlar ancak metabolik sendromun önemli bir komponenti olan intraabdominal yağ dokusu azalmasına, orantısız bir etkisi olduğu gösterilmiştir.

\section{f) Tip 2 diyabetten korunma}

Yaşam tarzı değişikliği (kilo verme, düzenli ılımlı fizik aktivite gibi) tip 2 diyabeti geciktirebilmekte veya koruyabilmektedir (Tuomilehto ve ark., 2001; Knowler ve ark., 2002).

\begin{tabular}{|c|c|}
\hline $\begin{array}{lll}\text { blo 1. } & \mathrm{Eq} \\
& \mathrm{ml} \\
& \mathrm{W}\end{array}$ & $\begin{array}{l}\text { iz ile glukoz kontrolündeki iyileşmenin } \\
\text { nel mekanizmasi (Ivy ve ark., 1999; } \\
\text { zewski ve ark., 2002) }\end{array}$ \\
\hline $\begin{array}{l}\text { İskelet kasındaki } \\
\text { biyokimyasal } \\
\text { adaptasyonlar }\end{array}$ & $\begin{array}{l}\text {-GLUT-4 aktivitesinde artma } \\
\text {-GLUT-4 içeriğinde artma } \\
\text {-İnsulin bağımsız glukoz taşıyıcılarında artma } \\
\text {-İnsulin bağımlı glukoz taşıyıcılarında artma } \\
\text {-Glukozun metabolizmasının enzim aktivasyonunda } \\
\text { ve içeriğinde artma } \\
\text {-Lipid metabolizmasında artma } \\
\text {-Glukoneogenezde azalma }\end{array}$ \\
\hline $\begin{array}{l}\text { İskelet kasındaki } \\
\text { yapisal } \\
\text { adaptayonlar }\end{array}$ & $\begin{array}{l}\text {-Kapiller yoğunluğunda artma } \\
\text {-İskelet kası kan akımında ve dağılımında artma } \\
\text {-Tip 2A fibrillerde ve kas fibril boyutunda artma }\end{array}$ \\
\hline $\begin{array}{l}\text { Sistemik } \\
\text { adaptasyonlar }\end{array}$ & $\begin{array}{l}\text {-Abdominal adipozitte azalma } \\
\text {-Sistemik inflamasyonda azalma } \\
\text {-Kan basıncında azalma } \\
\text {-Lipid pofilinde iyileşme } \\
\text {-Aerobik kapasitede artma }\end{array}$ \\
\hline
\end{tabular}

\begin{tabular}{|c|c|c|c|}
\hline \multicolumn{4}{|c|}{ Rölatif Yoğunluk } \\
\hline Yoğunluk & $\begin{array}{c}\mathrm{VO}_{2} \max \\
(\%)\end{array}$ & $\begin{array}{c}\text { Maksimum Kalp } \\
\text { Hızı (\%) }\end{array}$ & RPE \\
\hline Çok Hafif & $<20$ & $<35$ & $<10$ \\
\hline Hafif & $20-39$ & $35-54$ & $10-11$ \\
\hline Ilımlı & $40-59$ & $55-69$ & $12-13$ \\
\hline Zor & $60-84$ & $70-89$ & $14-16$ \\
\hline Çok zor & $>85$ & $>90$ & $17-19$ \\
\hline Maksimum oranda & 100 & 100 & 20 \\
\hline \multicolumn{4}{|c|}{$\begin{array}{l}\text { Maksimum kalp hızı:220-yaş; RPE: Egzersiz esnasında kişisel algı oranı } \\
\text { Maksimum oran: Sağlıklı yetişkinin maksimum egzersiz boyunca aldığı } \\
\text { ortalama değer }\end{array}$} \\
\hline
\end{tabular}

Tablo 3. Periferal nöropati sonucu koruyucu duyu kaybına uğrayan diyabetik hastalar için egzersizler (Zinman ve arkadaşları, 2004)

\begin{tabular}{ll} 
Kontrendike & Önerilen \\
\hline Koşu bandı & Yüzme \\
Uzun yürüyüşler & Bisiklete binme \\
Yavaş ve tempolu koşu & Kürek çekmek \\
Step egzersiz & Sandalye egzersizleri \\
& Kol egzersizleri \\
& Yük bindirmeyen egzersizler \\
\hline
\end{tabular}

\section{Alternatif egzersiz tipleri}

Tip 2 diyabete karşı koruyucu ve tedavi edici etkileri tartışmalı ve sınırlı olsa da egzersiz alternatifleri arasında yoga, tai chi, qigong gibi aktiviteler de mevcuttur.

Yoga kolay uygulanabilir, çeşitli psikolojik yararları olan, stresi azaltan, mental sağlığa iyi gelen bir egzersizdir (Innes ve ark., 2005; Aljasir ve ark., 2008). Kalbin parasempatik aktivitesini ve vagal kontrolünü arttırır, sempatik aktiviteyi ve sistemik inflamasyonu azaltır (Innes ve ark., 2005). 3-6 ay üzerinde düzenli yoga yapılması tip 2 diyabet gelişme riskini azaltır, sağlıklı erişkinlerde glukoz kontrolünü iyileştirir (Monro ve ark., 1992; Yogendra ve ark, 2004). Tai chi eski dönemlerden beri bilinen kareografik hareketlere dayanan, akıcı beden hareketleri ile yapılan, terapötik meditatif bir egzersizdir. Bu egzersizin yoğunluğu, 1lımlı kardiyovasküler egzersiz yoğunluğu (maksimum kalp hızı rezervi \%55-67) ile 
benzer bulunmuştur (Lan ve ark., 2008; Zhang ve Fu, 2008).

Qigong eski dönemlerden beri bilinen meditatif nefes teknikleri, sirküler ve spiral hareketler ile yapılan meditatif bir egzersizdir. Küçük çaplı çalışmalarda glukoz kontrolünde ve HbA1c düzeylerinde \%0,8-0,94 düşüş sağladığ1 görülmüştür (Xin ve ark., 2007).

\section{Diyabetik gebelerde egzersiz}

Amerikan Kadın Doğum Uzmanları Birliği (ACOG) tarafindan gebelikte, günde $30 \mathrm{dk}$ veya daha fazla 1 lımlı egzersiz önerilmektedir. Önerilen egzersiz tipleri yürüme, kondisyon bisikleti, düşük vuruşların olduğu aerobikler ve yüzmedir (ACOG, 2001).

Egzersiz sirasinda abdominal ve bel kaslarina kuvvet uygulanmasindan, aortakaval kompresyondan ve hipotansiyondan hasta korunmalıdır. Birinci trimestirden sonra supin pozisyondan kaçınılmalıdır (Artal, 1990). Kan glukoz düzeyi 90-140 mg/dL arasında iken egzersiz yapılması daha uygundur. Egzersiz program $45 \mathrm{dk}$ altında olmalı ve egzersizden 1-3 saat önce gıda tüketilmelidir. Egzersizde kullanılacak olan ekstremitelerden insulin enjeksiyonu yapılmamalıdır, ideali abdomenden insulin yapmaktır. İnsulin enjeksiyonu egzersizden 1 saat önce yapılmalıdır. Hastalar egzersiz öncesi (glukoz $<100 \mathrm{~g} / \mathrm{dL}$ ise ara ögün almalıdır), egzersiz sırasında (özellikle 45 dk'dan fazla egzersiz yapılacak ise), egzersiz sonrası (hipoglisemi açısından) kan glukoz düzeylerini kontrol etmelidirler. Kan glukozu $>250 \mathrm{mg} / \mathrm{dL}$ ve ketozis var ise egzersiz ertelenmelidir. Kan glukozu $>300 \mathrm{mg} / \mathrm{dL}$ ancak ketozis yok ise ezersiz sirasında ihtiyatlı olmak gerekmektedir (Richter ve Galbo, 2004). Kimi yazarlar, hiperglisemi sırasında egzersizden kaçınılmasını önermektedirler. Hipergliseminin sebep olduğu volüm açığı nedeni ile ortostatik hipotansiyon ve egzersiz sırasında yaralanma riski artmaktadır. Egzersiz rejimi hastanın diyabet tipine ve gebelik öncesi fizik aktivite durumuna göre planlanmalıdır. ACOG (2001) daha önce sedanter yaşamı olan gebe kadınların egzersiz sırasında kalp hızının 140'1 geçmemesini ( $\mathrm{VO}_{2} \max \% 60$-70) önermek- tedir. Egzersiz, gebelik öncesi düzenli egzersiz yapanlarda gebelik boyunca da devam edilebilir. Tip 1 diyabetikler hipoglisemi için yakından takip edilmelidirler. Tip 2 diyabetlilerde gebelik öncesi düzenli egzersiz yapanlar egzersizlerine gebelik boyunca devam edebilirler ancak gebelik öncesi sedanter yaşam sürenlerde egzersiz programı başlangıçta daha hafif yoğunlukta olmalıdır. Tolere edildikçe egzersiz yoğunluğu yavaşça arttırılabilir. Haftalık \%10'dan fazla artış yapılmamalıdır. Egzersiz yapılırken alarm semptomları açısından dikkatli olunmalıdır (Harris, 2005).

Egzersizi kesmek için gebelikte dikkat edilmesi gereken alarm belirti ve bulgular (Harris, 2005).

-Vajinal kanama

-Baygınlık hissi

-Fetal aktivitede azalma

-Yaygın ödem

-Bel ağrısı

Hastalar egzersiz sırasında uteruslarını palpe etmeli ve kontraksiyon hissederler ise egzersizi kesmeleri gerekmektedir (Setji ve ark., 2005).

Gebelikte egzersizin mutlak kontrendikasyonları (Metzger ve Coustan, 1998)

- Preterm eylem

- Erken membran rüptürü

- İmkompetan serviks

- 3. ve 4. trimestride dirençli kanama

- İntra uterin gelişme geriliği

- 26. haftadan sonra plasenta previa

- Gebelik hipertansiyonu

\section{Yaşlı diyabetiklerde egzersiz}

Yaşlanmaya bağlı kas kitlesindeki azalma, kuvvet kaybı ve sağlıklı yapıdaki azalma düzenli egzersiz ile iyileştirilebilmektedir. İnsulin sensitivitesindeki azalma kısmen fizik aktivite eksikliğinden kaynaklanmaktadır. Yaşlı populasyondaki tip 2 diyabetli hastalara, daha düşük seviyeli fizik aktivite programları uygulanabilir (Zinman ve ark., 2004).

\section{KAYNAKLAR}

ACOG Committee Opinion, 2001. Exercise during pregnancy and the postpartum period. Obstet. Gynecol. 99, 171-173.

Aljasir, B., Bryson, M., Al-Shehri, B., 2008. Yoga practice for the management of type II diabetes mellitus in adults: a systematic review. Evid Based Complement Altern Med. Electronically published ahead of print (doi:10.1093/ecam/nen027).

American Diabetes Association, 2011. Diabetes Care, Vol 34, Supplement 1, January, pp:24-25.Artal, R., 1990. Exercise and diabetes mellitus in pregnancy: A brief review. Sports. Med. 9, 261-265.

Aubert, R.E., Herman, W.H., Waters, J., Moore, W., Sutton, D., Peterson, B.L., Bailey, C.M., Koplan, J.P., 1998. Nurse case management to improve glycemic control in diabetic patients in a health maintenance organization: A randomized, controlled trial. Ann. Intern. Med. 129, 605-612.

Boule, N.G., Kenny, G.P., Haddad, E., Wells, G.A., Sigal, R.J., 2003. Meta-analysis of the effect of structured exercise training on cardiorespiratory fitness in type 2 diabetes mellitus. Diabetologia. 46, 1071-1081.

Brown, M.D., Moore, G.E., Korytkowski, M.T., McCole, S.D., Hagberg, J.M., 1997. Improvement of insulin sensitivity by short-term exercise training in hypertensive African American women. Hypertension. 30, 1549-1553.

Castaneda, C., Layne, J.E., Munoz-Orians, L., Gordon, P.L., Walsmith, J., Foldvari, M., Roubenoff, R., Tucker, K.L., Nelson, M.E., 2002. A randomized controlled trial of resistance exercise training to improve glycemic control in older adults with type 2 diabetes. Diabetes Care. $25,2335-2341$.

Catherine, A., Mullooly, M.S., Karen, L., Kemmis, P.T., 2005. Diabetes Educators and the Exercise Prescription. Diabetes Spectrum. 18, 108113.

David, C., Wright, M.S., Pamela, D.S., 2001. Optimal exercise intensity for individuals with impaired glucose tolerance. Diabetes Spectrum. $18,93-97$.

Dela, F., von Linstow, M.E., Mikines, K.J., Galbo, H. , 2004 . Physical training may enhance beta-cell function in type 2 diabetes. Am. J. Physiol. Endocrinol. Metab. 287, 1024-1031.

Douen, A.G., Ramlal, T., Cartee, G.D., Klip, A., 1990. Exercise modulates the insulin-induced translocatio of glucose transporters in rat skeletal muscle. FEBS. Lett. 261, 256-260.

George, D., Harris, M.D., Russell, D.W., 2005. Diabetes management and exercise in pregnant patients with diabetes. Clin. Diabetes. 23, 165168. 
Grebe, S.K.G., Smith, R.B.W., 1995. Clinical audit and standardized follow-up improve quality of documentation in diabetes care. N. Z. Med. J. 108, 339-342.

Gulve, E.A., 2008. Exercise and glycemic control in diabetes: Benefits, challenges, and adjustments to pharmacotherapy. Phys. Ther. 88, 12971321.

Harris, G.D., 2005. Exercise and the pregnant patient: A clinical overview. Women Health Primary Care. 8, $79-86$.

Innes, K.E., Bourguignon, C., Taylor, A.G., 2005. Risk indices associated with the insulin resistance syndrome, cardiovascular disease, and possible protection with yoga: A systematic review. J. Am. Board. Fam. Pract. 18, 491-519.

Ivy, J.L., Zderic, T.W., Fogt, D.L., 1999. Prevention and treatment of non-insulin-dependent diabetes mellitus. Exerc. Sport. Sci. Rev. 27, $1-35$.

King, D.S., Baldus, P.J., Sharp, R., Kesl, L.D., Feltmeyer, T.L., Riddle, M.S., 1995. Time course for exercise induced alterations in insulin action and glucose tolerance in middle-aged people. J. Appl. Physiol. 78, 17-22.

King, D.S., Feltmeyer, T.L., Baldus, P.J., Sharp, R.L., Nespor, J., 1993. Effects of eccentric exercise on insulin secretion and action in humans. J. Appl. Physiol. 75, 2151-2156.

Knight K, Badamgarav E, Henning JM, Hasselblad V, Gano AD Jr, Ofman JJ, Weingarten SR: A systematic review of diabetes disease management programs. Am J Managed Care 11:242-50, 2005.

Knowler, W.C., Barrett-Connor, E., Fowler, S.E., Hamman, R.F., Lachin, J.M., Walker, E.A., Nathan, D.M., 2002. Diabetes Prevention Program Research Group. Reduction in the incidence of type 2 diabetes with lifestyle intervention or metformin. N. Engl. J. Med. 346, $393-403$.

Konca, L., Ayvaz, G., 2011. Tip 2 diyabetes mellitusun insulin dışı tedavisi. Endokrinoloji Metabolizma ve Diyabet, 2.bask1, Metin Özata, ed. İstanbul Tip Kitabevi Yayıncıl1k, İstanbul, pp. 572-582.

Lan, C., Chen, S.Y., Lai, J.S., 2008. The exercise intensity of tai chi chuan. Med. Sport. Sci. 52, 12-19.

Metzger, B.E., Coustan, D.M., 1998. Organizing Committee. Summary and recommendations of the fourth international workshop-conference on gestational diabetes mellitus. Diabetes Care. 21, B161-B167.

Mitchell, T.H., Abraham, G., Schiffrin, A., Leiter, L.A., Marliss, E.B., 1988. Hyperglycemia after intense exercise in IDDM subjects during continuous subcutaneous insulin infusion. Diabetes Care. 11, 311-317.

Mogensen, C.E., 2002. Nephropathy. In Handbook of Exercise in Diabetes. 2nd ed. Ruderman, N., Devlin, J.T., Kriska, A., Alexandria, V.A., American Diabetes Association, p. 433-449.

Monro, R., Power, J., Coumar, A., Dandona, P., 1992. Yoga therapy for NIDDM: A control trial. Complement Med. Res. 6, 66-68.

Nelson, M.E., Rejeski, W.J., Blair, S.N., Duncan, P.W., Judge, J.O., King, A.C., Macera, C.A., Castaneda-Sceppa, C., 2007. Physical activity and public health in older adults: Recommendation from the American College of Sports Medicine and the American Heart Association. Med. Sci. Sports. Exerc. 39, 1435-1445.

Pariser, G., Ann, D,M., Gillette, P., Stephen, W., 2010. Outcomes of an education and exercise program for adults with Type 2 diabetes, and comorbidities that limit their mobility: A Preliminary Project Report. Cardiopulm Phys. Ther. J. 21, 5-12.

Peyrot, M., Rubin, R.R., Lauritzen, T., Snoek, F.J., Matthews, D.R., Skovlund, S.E., 2005. Psychosocial problems and barriers to improved diabetes management: results of the cross-national Diabetes Attitudes, Wishes, and Needs study. Diabet. Med. 22, $1379-1385$.

Richter, E.A., Galbo, H., 2004. Diabetes and exercise. Int. Diabetes. Monitor. 16, 1-9.

Rogers, M.A.,Yamamoto, C., King, D.S., Hagberg, J.M., Ehsani, A.A., Holloszy, J.O., 1988. Improvement in glucose tolerance after 1 week of exercise in patients with mild NIDDM. Diabetes Care. 11, 613-618.

Schell, T.C., Wright, G., Martino, P., Ryder, J., Craig, B.W., 1999. Post-exercise glucose, insulin, and C-peptide responses to carbohydrate supplementation: Running vs. resistance exercise. J. Strgth. Cond. Res. 13, 372-380.

Schriger, D.L., Baraff, L.J., Rogers, W.H., Cretin, S., 1997. Implementation of clinical guidelines using a computer charting system: Effect on the initial care of health care workers exposed to body fluids. JAMA. 278, 1585-1590.

Setji, T.L., Brown, A.J., Feinglos, M.N., 2005. Gestational diabetes mellitus. Clin. Diabetes. 23, 17-24.

Sherman, W.M., Lash, J.M., Simonsen, J.C., Bloomfield, S.A., 1992. Effects of downhill running on the responses to an oral glucose challenge. Int. J. Sport. Nutr. 3, 251-259.

Sigal, R.J., Kenny, G.P., Boule, N.G., Wells, G.A., Prud'homme, D., Fortier, M., Reid, R.D., Tulloch, H., Coyle, D., Phillips, P., Jennings, A., Jaffey, J., 2007. Effects of aerobic training, resistance training, or both on glycemic control in type 2 diabetes: Arandomized trial. Ann. Intern. Med. 147, 357-369.

Snowling, N.J., Hopkins, W.G., 2006. Effects of different modes of exercise training on glucose control and risk factors for complications in type 2 diabetic patients: a meta-analysis. Diabetes Care. 29, 2518-2527.

Steppel, J.H., Horton, E.S., 2008. Diyabetes mellituslu hastalarda egzersiz. Joslin's Diabetes Mellitus, 14. bask1, Khan, C.R., Weir, G.C., King, G.L., Jacobson, A.M., Moses, A.C., Smith, R.C., eds. Istanbul Medikal Yayıncılık, İstanbul, pp. 649-656.

Thomas, D.E., Elliott, E.J., Naughton, G.A., 2009. Exercise for type 2 diabetes mellitus. The Cochrane Library. issue 1, 1-55.

Tuomilehto, J., Lindstrom, J., Eriksson, J.G., Valle. T.T., Hamalainen, H., Illanne-Parikka, P., Keinanen-Kiukaaniemi, S., Laakso, M., Louheranta, A., Rastas, M., Salminen, V., Uusitupa, M., 2001. Prevention of type 2 diabetes mellitus by changes in lifestyle among subjects with impaired glucose tolerance. N. Engl. J. Med. 344, 1343-1350.

Wang, J.H. , 2008. Effects of tai chi exercise on patients with type 2 diabetes. Med. Sport. Sci. 52, 230-238.

Wojtaszewski, J.F., Nielsen, J.N., Richter, E.A., 2002. Invited review: Effect of acute exercise on insulin signaling and action in humans. J. Appl. Physiol. 93, 384-392.

Wood, D.J., Rumsby, M.G., Warr, J.R., 1996. Monensin and verapamil do not alter intracellular localisation of daunorubicin in multidrug resistant human KB cells. Cancer Lett. 108, 41-47.

World Cancer Report, 2003. International Agency for Research on Cancer.

Xin, L., Miller, Y.D., Brown, W.J., 2007. A qualitative review of the role of qigong in the management of diabetes. J. Altern. Complement. Med. 13, 427-433.

Yecies, J.L., Manning, B.D., 2011. mTOR links oncogenic signaling to tumor cell metabolism. J. Mol. Med. 89, 221-228.

Yogendra, J., Yogendra, H.J., Ambardekar, S., Lele, R.D., Shetty, S., Dave, M., Husein, N., 2004. Beneficial effects of yoga lifestyle on reversibility of ischaemic heart disease: Caring Heart Project of the International Board of Yoga. J. Assoc. Physicians. India. 52, $283-289$.

Zhang, Y., Fu, F.H., 2008. Effects of 14-week tai ji quan exercise on metabolic control in women with type 2 diabetes. Am. J. Chin. Med. 36, $647-654$.

Zinman, B, Ruderman, N., Campaigne, B.N., Devlin, J.T., Schneider, S.H. 2004. Physical activity/exercise and diabetes. Diabetes Care. 27 Suppl 1, 58-62. 